\title{
Shaping the Chemical Industry and Saving the Cotton Industry: Role of Sir P C Ray, a Visionary Entrepreneur of British India
}

\author{
Syamal Chakrabarti*
}

(Received 15 May 2018; revised 15 June 2018)

\begin{abstract}
India was treated as the 'industrial hub of the world' during the seventeenth and eighteenth centuries. However, the country lost its prominence and was transformed into an importing country from an exporting one due to two important reasons. This kind of transformation had been discussed by Karl Marx in one of his famous articles. Industrialization later slowly diversified and two units deserve special mention. One is the Tata Iron and Steel Company (TISCO) founded by J N Tata and the other is the Bengal Chemical and Pharmaceutical Works (BCPW) founded by Sir Prafulla Chandra Ray. The initial history of growth of BCPW has been discussed tracing the ups and downs in the fortune of the company at different times. The second part of the article describes the tireless efforts of the scientist in saving the capitals of the shareholders of a textile company named Banga Sree Cotton Mills Limited whose shares he had endorsed earlier.
\end{abstract}

Key words: Bengal Chemical and Pharmaceutical Works (BCPW), Cotton mills, Industrial Revolution, Manicktala, Panihati, Precidency College Kolkata.

\section{BACKGROUND}

India was called the 'industrial workshop of the world' during seventeenth and eighteenth centuries, e.g. the demand for Indian cotton goods in England during the above mentioned two centuries was unprecedented. Woolen and silk items were also in high demand. The big capital (finance capital) might have a different role to play in the era of present day globalization but the situation was different during that period. They introduced several acts and legislations to restrict the import of Indian cottons and other textile materials in England.

India was undoubtedly ahead of the British so far the industrialization is concerned. However, it took an entirely different path due to certain developments. The first one is the industrial revolution in Britain and the second one is the loss of freedom to East India Company. The British rulers initiated one way free trade in order to throttle the business of India.

Indian market became flooded with machine-produced goods at a lower price. India was then forcibly transformed from being a country of combined agriculture and manufacturers into an agricultural colony of British manufacturing capitalism. Karl Marx wrote,

Till 1813 India had been chiefly an exporting country, while it now became an importing one; and in such a quick progression, that already in 1823 the rate of exchange, which had generally been $2 / 6$ per rupee, sunk down to $2 /$ per rupee. India, the great workshop of cotton manufacture for the world, since immemorial times, became now inundated with English twists and cotton stuffs.

\footnotetext{
* Department of Chemistry, University College of Science and Technology, 92 A P C Road, Kolkata-700009, India, Email: scchem1957@gmail.com
} 
After its own produce had been excluded from England, or only admitted on the most cruel terms, British manufactures were poured into it at a small and merely nominal duty, to the ruin of the native cotton fabrics once so celebrated. In 1780 the value of British produce and manufactured amount only to $£ 386152$, the bullion exported during the same year to $£ 15041$, the total value of export during 1780 being $£ 12,648,616$, so that the Indian trade amounted to only 1-32 of the entire foreign trade. In 1850 the total exports to India from Great Britain and Ireland were $£ 8024,000$ of which cotton goods alone amounted to $£ 5,220,000 \ldots . . .($ Marx, 1853).

There were a number of prominent sectors where industrialization and marketing were running in the full swing. In order to name a few, they were mining, jute, steel and cotton sectors. It is interesting to note, except the textile factories, all other sectors by this time were controlled by the British owners. In the area of mining, there was coal only. However, the development in this area was relatively slow. There was a great demand for jute for which it flourished rapidly. Jute industries were mainly controlled by the Britishers whereas the cotton industries were mainly run by the native Parsees.

There were some stray attempts during nineteenth century to develop iron and steel industry in India. The most successful attempt had been taken by Jamshedji Tata, a native Parsee. Having scientific and technical advice from P N Bose, an experienced geologist and a graduate from the University of London, Jamshedji established Tata Iron and Steel Company in 1907. The company started producing pig iron in 1911 and steel from next year.

Excluding the above mentioned important sectors, there were other sectors such as woolen mills, breweries, paper making, tanning, vegetable oil processing, glass making, leather goods manufacturing etc. most of which were not sound during the period. We have not mentioned the history of chemical and pharmaceutical industries in British India. The pharmaceutical industry was established in India primarily to cater to the requirements of British Army suffering from tropical diseases. Accordingly, almost all the early pharmaceutical units in India engaged in production as well as research, focused exclusively on drugs/vaccines for infective tropical diseases. Most of the pre-independence pharmaceutical companies were owned by the British, perhaps with the single exception of Bengal Chemical and Pharmaceutical Works. The production of pharmaceuticals started in India since the late nineteenth century. But India continued to remain import dependent and 'an exclusive preserve for unloading the products of the British drug industry' (Rangarao, 1975, p.15). In most cases, the British and other European manufacturers used to market their products either through their own Indian branches or through various trading companies.

\section{Bengal Chemical and Pharmaceutical Works: Formative Years}

Let us discuss the initial phase of formation of Bengal Chemical and Pharmaceutical Works (BCPW). We all know that Sir P C Ray was the founder of this well-known organization. Prafulla Chandra was awarded D.Sc. degree from the University of Edinburgh and joined Presidency College, Calcutta in 1889. He became absorbed in teaching and research but he had also a plan in his mind. Prafulla Chandra asked himself in his autobiography,

\section{How to utilize the thousand and one raw products which Nature in her bounty scattered broadcast in Bengal? (Ray, 1996, p. 92).}

As a member of the Edinburgh Chemical Society, Prafulla Chandra visited a number of industries in England and Scotland. He also utilized his 'Hope prize' not only to visit the research laboratories of the leading scientists of Europe but also to look after the fruits of industrial revolution. According to him,

In England and Scotland Chemical Works are conducted on an extensive scale, there are sister industries side by side, the one dependent or 
deriving nourishment from the other. I had read in my text books that sulphuric acid is the mother of all other industries. A visit to mammoth sulphuric acid works of Tennant \& Co., St. Rollox, Glasglow, convinced me of its significance (Ray, 1996, p. 94).

Not only sulphuric acid, a country also needs good quality steel for its development. In India, production of steel was brought about by Tata Iron and Steel Company very successfully. In his autobiography, Ray appreciated J N Tata for his pioneering contribution and the fruition of the great enterprise.

One needs capital in order to establish an industry of sulphuric acid which was not available to Prafulla Chandra at the beginning of his career. Let us quote him,

\section{.....I had rented 91, Upper Circular Road, which was to be my residence for the next quarter of a century. It was also here that the foundation was laid of the Bengal Chemical and Pharmaceutical Works.}

Prafulla Chandra realized that chemistry and industry had to work hand in hand. He started his industrial venture by extracting citric acid from lemon juice. The lemons were not available in the local markets at a cheap price for which his first attempt was not financially viable. However, he did not drop his idea. He understood that such articles could be manufactured on a small scale and would find a ready sale in the market. After so many preliminary attempts, the scientist became ready for pharmaceutical preparations. But a proper market survey is necessary before producing a material. Prafulla Chandra did the same by moving around the important drug stores in Calcutta. He enquired the amount of imports of different drugs made on the basis of British Pharmacopoeia. Butto Kristo Paul and Co. was a premier drug store in North Calcutta. The owner assured good number of purchasers provided the right sort of things are made.

Though the official declaration of the beginning of BCPW was 1901, the previous few years were not less important.
Pafulla Chandra's monthly salary was Rs 250/- from which he kept very little for himself. He started his venture with a capital of Rs 800/only in his residential laboratory. Prafulla Chandra stated,

...... I took to preparartions of the British Pharmacopoeia. I was relieved to find that Syrup Ferri Iodidi, Liquor Arsenicalis, Liquor Bismuth, Spritus AEtheris Nitrosi and several tinctures did not present much difficulty to a trained chemist.......And now I seriously thought of pushing my preparations in the market (Ray, 1996, p. 99-100).

Marketing of a product is intimately associated with its advertisement. The following was one such advertisement in the widely circulated vernacular paper, 'The Sanjivani' (November 3, 1894) (Fig. 1).

In the above advertisement, it had been told that 'some three hundred medicines have been prepared and are for sale.' This was impossible with a capital of Rs 800/- only. The fact is that Dr. Amulyacharan Bose, a physician with a very good practice shared a comfortable sum into the business. A good number of very famous doctors namely R G Kar, Nilratan Sircar and Suresh Prasad

\section{BENGAL CHEMICAL AND PHARMACEUTICAL WORKS}

91, UPPER CIRCULAR ROAD, CALCUTTA

With the help of Dr. Prafulla Chandra Ray D.SC (Edin) and the well-known medical practitioner Dr. Amulyacharan Bose M.B.., in this allopathic manufacturing concern some three hundred medicines have been prepared and are for sale.

Our preparations are made according to the latest scientific methods. Price list on application. The name of only one is given below. Syrrup of Hypophosphite of Lime for colds, coughs, catarrh, asthma, phthisis, bronchitis and other lung diseases: a never failing remedy. It is sweet and agreeable to the taste and of beautiful rose colour. Trial of last two years has proved that because it is freshly prepared its efficacy is superior to that of the imported article. The leading physicians of Calcutta are prescribing it.

Fig. 1. Advertisement of the Products of BCPW; 'The Sanjivani' (November 3, 1894) 
Sarbadhikary used to prescribe the medicines prepared by BCPW.

Amulyacharan was not merely a financial partner. He gave a new direction in the business. 'He consulted several Kavirājas and collected from them formulae and recipes for the Ayurvedic preparations, e.g extracts of Kālamegh....and Kürchi...; syrup of Vāsaka; Aqua Ptychotis (Ajowan water)....Amulyacharan himself took the lead in boldly using these in his prescriptions ....Our newly introduced indigenous drug preparations thus began to make headway on their own merits' (Ray, 1996, p. 104).

The journey of BCPW started in 1892. It became 'The Bengal Chemical and Pharmaceutical Works Limited' on April 12, 1901. Prafulla Chandra after coming back from Presidency College would go through previous day's orders and arrange accordingly.

\begin{abstract}
There were problems of procurement of raw material, production and sales. Prafulla Chandra had appointed a broker on commission on sales and procurement of raw material but that was only a limited help. The most formidable obstacle he faced was the prejudice of the local dealers, customers and even physicians - they all preferred imported medicines to those manufactured locally. The local drug market was in the grip of persons whom Prafulla Chandra called illiterate banias. They did not have the spark of patriotism in them (Mukherjee, 2004, p. 10).
\end{abstract}

Bengal Chemical was at the height of its production during 90's in the nineteenth century. Satish Chandra Sinha, a Chemist by training and also a law degree holder, brother-in-law of Dr. Amulyacharan Bose, was inspired by Prafulla Chandra to join Bengal Chemical instead of joining in the legal profession. Satish Chandra also brought some capital for the company. It was painful that after working for about one and a half year, he became a victim of accidental death while working with deadly poisonous hydrocyanic acid. It might be the first recorded death of chemical poisoning in industry in our country. Prafulla
Chandra, for few days, was at a loss. He told, 'I had again to take all the responsible duties on my shoulders' (Ray, 1996, p. 108).

\section{Bengal Chemical and Pharmaceutical Works: As Public Limited Company}

Tragedy became deeper when Amulyacharan died of pneumonic plague contracted during his professional work. He died on September 4, 1898. The scientist again became alone. He immediately understood that in order to save the factory, it had to be converted into a public limited company. We mentioned earlier that the day was 12 April 1901. In a sense, it was the first public limited pharmaceutical company in India.

From the history book of the Company, we quote,

The Bengal Chemical \& Pharmaceutical Works Limited that time was with an authorized capital of Rs 25000. Five days later, the stock, assets and goodwill of the old private concern were bought by the new company. It started business at the same Upper Circular Road premises where Prafulla Chandra had his residence (Mukherjee, 2004, p. 12).

The first ordinary General Meeting of shareholders of the company was held on May 5, 1901 at the residential premise of P C Ray. The company needed more space and fund. The 'articles of association' was signed by Prafulla Chandra, Kartick Chandra Bose, Bhootnath Paul, Chandra Bhusan Bhaduri, and Charuchandra Bose besides others. It must be noted that Prafulla Chandra did not forget Amulyacharan and Satischandra during the preparation of the articles of the association. Nripendranandini Bose, wife of Amulyacharan, and Promilasundari Sinha, wife of Satischandra were included as shareholders of the company. The proceedings of the first ordinary general meeting of the shareholders was written by Prafulla Chandra himself (Fig. 2). 


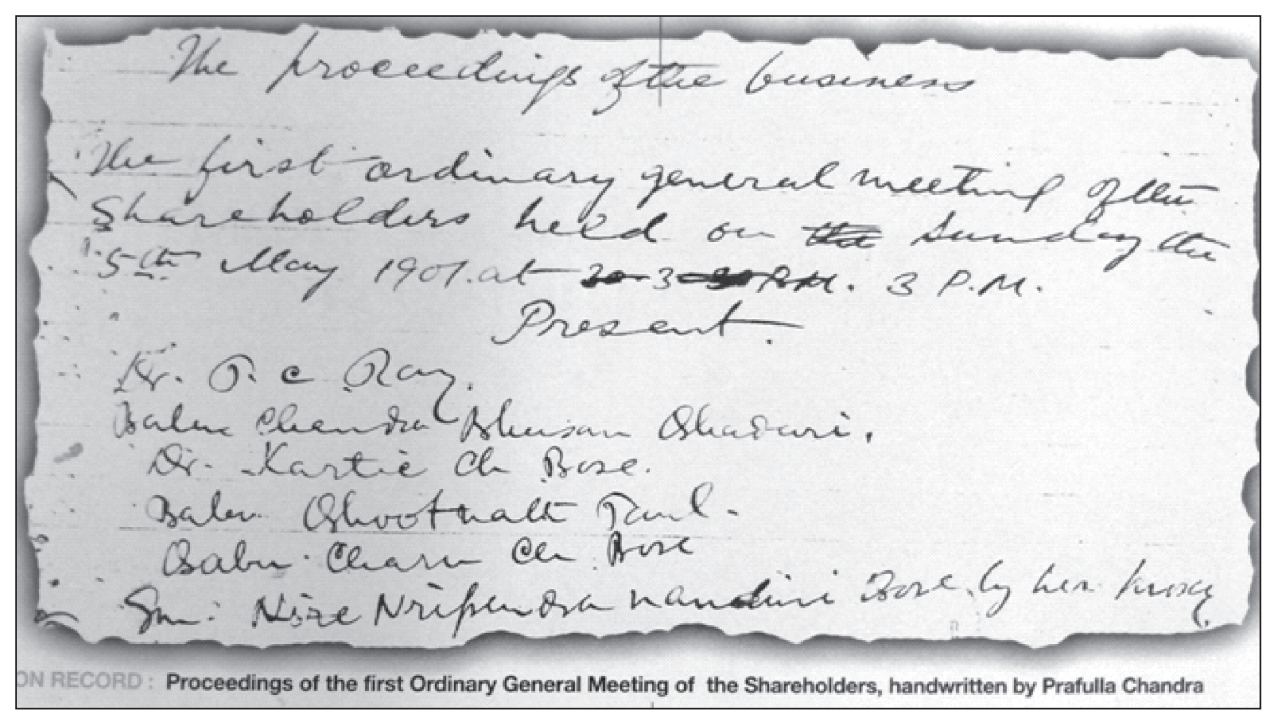

Fig. 2. Proceedings of the First Ordinary General Meeting of the Shareholders

Kartick Chandra Bose, a medical practitioner became the first Managing Director of the Company. He stood first in all the medical examinations. He established 'Dr. Bose's Laboratory', 'Standard Drug Stores', 'Standard XRay Laboratory', 'Standard Clinical Laboratory', 'Calcutta Optical Company', 'Beleghata Engineering Works'and 'Rajlaxmi Sugar Mill' - an outstanding business and industrial entrepreneur. He published health magazines in Bengali, English, Hindi and Urdu languages. He edited the Bengali one for long forty five years. Dr. Bose with another physician Gananath Sen demonstrated 'the first modern evidence for successful therapy of violent mental disorders with the extracts of the plant Rauwolfia serpentina in 1931. During fifties, the western scientists followed this work to gain new insights into brain Chemistry and develop anti-psychotic drugs' (Sen and Bose, 1931).

Bhootnath Paul was the owner of M/S B. K. Paul \& Co, one of the largest dealers in medicine in Calcutta. When Bhootnath came to know that Bengal Chemical is manufacturing medicines following British Pharmacopoeia, he used to place orders regularly in large amounts.
Chandrabhusan Bhaduri was employed in Presidency College as a demonstrator in the Department of Chemistry. He helped Prafulla Chandra in designing different chemical laboratories. When Ray planned to purchase a small sulphuric acid plant near Tollygunge, he accompanied Chandrabhusan and his younger brother Kulbhusan (M.A. in Chemistry) to visit the site.

After the first general meeting of BCPW Director Kartick Chandra also became the medical advisor of the company and Director Bhootnath Paul became the chief agent of BCPW. Chandrabhusan was authorized as engineering chemist and Charuchandra became the manager of the company. There were employees under the names operative chemist, accountant and head Bottler.

Kavirāj Upendranath Sen became a Director in 1904. He was known for his Ayurvedic medicine preparation and as a publisher of Ayurvedic books. He financed a good amount by which a three-acre land was purchased in Manicktala area and the manufacturing section of BCPW was shifted there from 91, Upper Circular Road, Calcutta. From a 'Cottage industry', BCPW was improving into a 'modern industry'. The first plant 
was the plant for sulphuric acid preparation (Chamber Process) which went into operation in 1907. It was installed by the Indians without the help of any foreign experts - a brilliant example of self-reliance.

Dr. Travers, the first Director of Indian Institute of Science, Bangalore submitted a report to the University of Calcutta where he mentioned,

The design and the construction of the sulphuric acid plant and the plant required for the preparation of drugs and other products involved a large amount of research work of the kind which is likely to be the greatest service to this country.

Chandrabhusan was credited for radically altering the crude and elementary processes into newer ones. He introduced stream pans, disintegrators, vacuum Stills, filter presses and other modern pharmaceutical appliances.

Rajsekhar Bose, also a very well-known name in Bengali literature as Paraśurām joined BCPW as a chemist. He obtained B.A. and M.A. in Chemistry standing first class first in both examinations. Later he also got a law degree. He was promoted to the post of Company Secretary within a very short period and in 1906 to Factory Manager. Rajsekhar became a member of the Board of Directors in 1924 (Fig. 3). His contribution in BCPW was immense. The centennial history publication mentioned him as a thinker of product development, guiding research, coining brand names, devising market strategies, writing advertisements and finalizing expansion plans.

During first decade of the twentieth century, along with chemicals and pharmaceuticals, BCPW was manufacturing different scientific apparatus. The company also took up the job of designing, equipping and fitting science laboratories in different parts of the country. What about the sales? The following figures are the answers.

An employee of the company named Probodh Chandra Chattopadhyay developed 'oxygen apparatus' and took its patent giving
Table 1. BCPW Sales during 1901-1915

\begin{tabular}{|cc|}
\hline Year & Amount (in rupees) \\
\hline 1901 & 25,371 \\
1910 & $3,00,000$ \\
1915 & $5,00,000$ \\
\hline
\end{tabular}

money from his own. It must be noted that the Board of Directors sanctioned him $50 \%$ of the profit. The company, by that time, was producing Chemical Balances, Gas Burners, Fire Extinguishers and hospital appliances. Prafulla Chandra once said, 'The establishment of a large chemical industry was the dream of my youth. That dream is being given effect to by two of my pupil' (Mukherjee, 2004, p. 50). One pupil was Rajsekhar. Another one was Satishchandra Dasgupta, born in the same year as Rajsekhar, did his M.A. in Chemistry from Presidency College, Calcutta. Satishchandra joined in the same year with Rajsekhar and became Factory Superintendent within a short period. He innovated Chemical fire extinguisher named 'Fire King'. This innovation brought a huge amount of profit to the company. Satishchandra left BCPW in 1926 in order to work full time with Gandhiji. When Prafulla Chandra

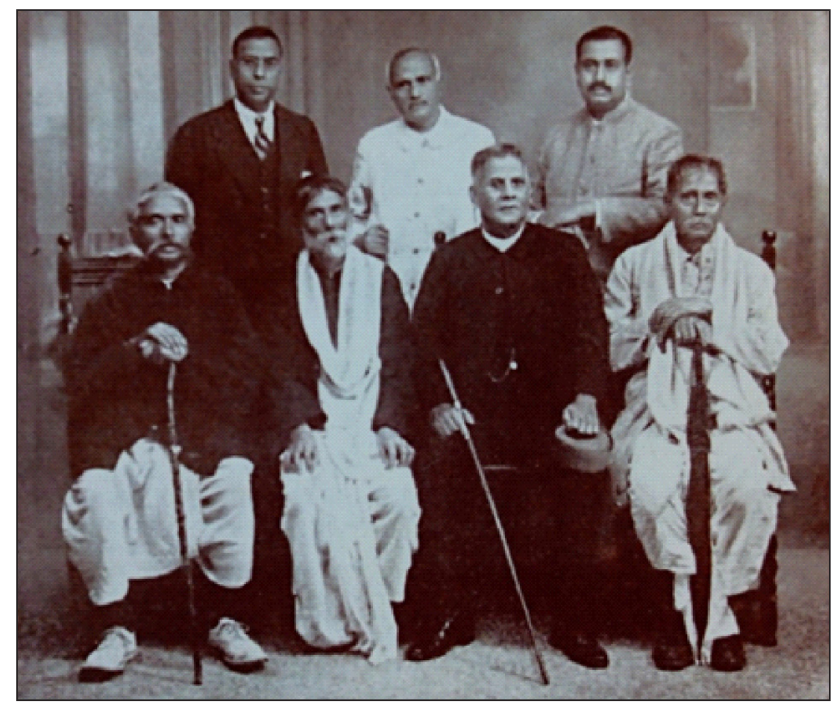

Fig. 3. Board of Directors of BCPW (1924) (Standing L to R) Rai Bahadur Haridhan Dutt, Satyananda Bose and Rajsekhar Bose. (Sitting L to R) W. M. Roy, Sir P. C. Ray, Rai Bahadur Chunilal Bose and Rai Saheb Kunja Behari Basu. 
was addressing meeting of the shareholders in August, 1921, a section of them raised voice against the functioning of some senior officials. Prafulla Chandra replied,

The share-holders have not realized what they owe to Rajsekhar and Satishchandra, the Manager and the Factory Superintendent. If Bengal fails to appreciate their splendid services, I, ever in my present old age, have the confidence to build with the aid of these men a new industry in a new place (Mukherjee, 2004, p. 50)

The second plant of BCPW started at Panihati, $13 \mathrm{Km}$ away from Kolkata. A plant for coal tar distillation, a unit for large scale preparation of alum and a larger unit for sulphuric acid manufacture by contact process were introduced during 1920-1921. A third unit was also set up in Bombay in 1934. However, from that time, a group of share holders asked for more dividends rather than spending the capital for expansion. They also objected Ray's plea for keeping away certain portion of the profit for modernization of the factories. Prafulla Chandra also suggested induction of professional scientists on the Board, diversification and spending more on research and development. He himself felt a doubt about his presence in BCPW and submitted his resignation from the Board on $26^{\text {th }}$ August 1939, just one week ahead of the Second World War. When he was requested to withdraw his resignation he replied as follows:

My joining the Board is out of question specially in view of their attitude towards the research work as evidenced by their letter to Dr. M. N. Saha. I am glad I can wash my hands of all the responsibility in the matter of the failure of the Bengal Chemical in the research line at this psychological moment. The fixed running idea of yours and Directors had always been to squeeze out everything (like sugarcane) as long as they could offer large dividends.

(Sd)

P. C. Ray

An evicted and homeless stranger in the land (i.e. BCPW) he once called his own ${ }^{1}$

\section{Banga Sree Cotton Mills Ltd.}

The first cotton mill in India was established in 1818 by the British people. It was only as late as 1905 that the modern cotton textile industry of Bengal was established as a result of purely indigenous Bengalee enterprise during the Swadeshi Movement. The first cotton mill by the Bengalees was Banga Laxmi Cotton Mills, Serampore established in the year 1906 under the leadership of Sir Surendranath Bandyopadhyay. Then we had the following Cotton Mills in Bengal.

Table 2. Cotton Mills in Bengal

\begin{tabular}{|lc|}
\hline Name & $\begin{array}{c}\text { Year of } \\
\text { establishment }\end{array}$ \\
\hline Mohini Mills, Kushtia & 1908 \\
Dhakeswari Cotton Mills, Dacca & 1924 \\
Maha Laxmi Cotton Mills, Palta, & 1930 \\
24 Parganas & \\
Bangeswari Cotton Mills, Serampore & 1931 \\
Banga Sree Cotton Mills, Sodepur & 1932 \\
East India Cotton Mills, Mourigram & 1933 \\
Basanti Cotton Mills, Panihati & 1936 \\
Prafulla Chandra Cotton Mills, Khulna & 1936 \\
\hline
\end{tabular}

P C Ray wrote an article in Bengali in the journal Basumati (Ray, 1344 B.S.) where he cautioned the Mills Owners and Managers to take experiences from the others in order to run their Mills. Prafulla Chandra observed that a number of people suddenly issue advertisements for big companies, and begin to sell shares as managing agents. According to him, the process is quite unbecoming of a good entrepreneur. In fact, exactly because of this reason, Banga Sree Cotton Mills faced the serious problem where the scientist tried his best to intervene. During the troubled period, Prafulla Chandra made an appeal to the people to buy shares of this establishment. People responded and the number of shareholders became 2000 two years later. Prafulla Chandra expressed satisfaction as 'Patron' of the company. Few years

\footnotetext{
1 P C never drew any Directors' fee and donated the same for employees welfare. His holdings in BCPW and industries amounted Rs. 56000/- which he donated in a trust fund for widows (Mukherjee, 2004, p. 36).
} 


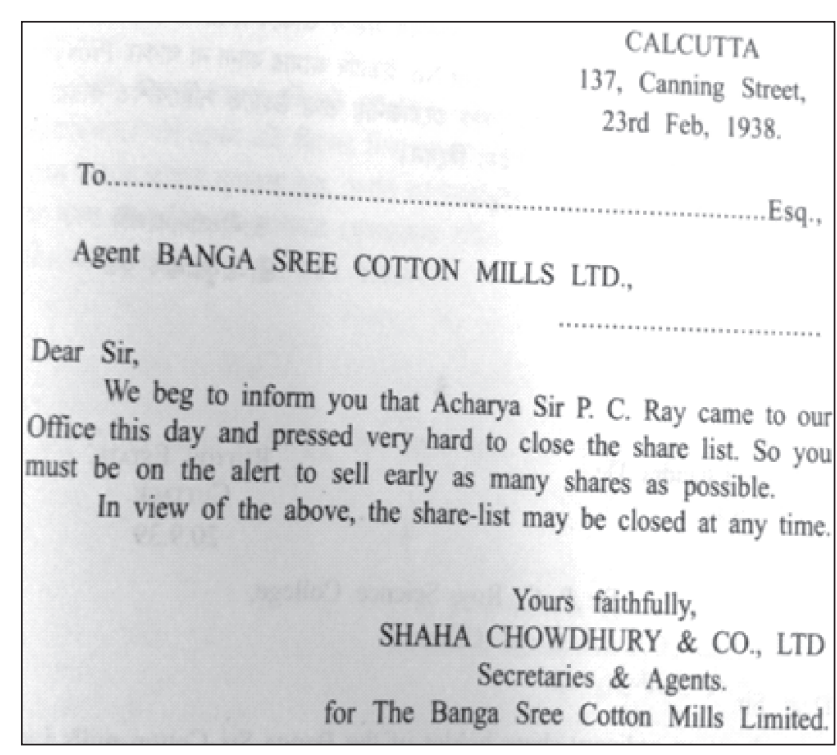

Fig. 4. Appeal of the managing agent

Dear Sir,
I have gone through the report of the Directors of the Banga Sri
mills Ltd. Personally I think that some of the items of expenditure are
very exorbitant indeed, E.g. travelling allowance etc etc, Morever, it pains
me to find that the dividend will only be given to those who are holders
of the preference shares. This is very unfair, for it will be a great
disappointment to the ordinary shareholders, if after so many years the
Company decides that they are not to get a farthing by way of dividend.
I hope you will exercise your influence in the matter and do the needful.
Myself and some of my friends here have taken shares on the strength
of your fair name only, for, living as we do far away from Bengal, we
cannot possibly be in touch with such concerns as the Banga Sri mills.
I, therefore, hope that you will do all you can in the meeting of October
6th to safeguard our interest. With respects,
Rf. I remain
The Proxy form is herewith enclosed.
Allotment no 9377

Fig. 5. Appeal to share-holders authorizing capital withdrawing rights to PC Ray

later, when the functioning of the managerial staffs were not satisfactory, P C Ray suggested the agent of the Company to stop taking more shares (Fig.4).

The financial situation of the company was deteriorating day by day. P C Ray became deeply concerned and published a letter in the widely circulated 'The Anandabazar Patrika' on $17^{\text {th }}$
September, 1939 (During the time of Second World War).

He made an appeal to all share-holders of the industry to send letters authorizing the capital withdrawing rights to him. There was an immense response. The scientist received huge number of letters from the share-holders. We are showing above, a letter of this kind (Fig 5.) (Most of the letters were written in Bengali, Chakrabarti, 2011).

\section{Conclusion}

Prafulla Chandra pioneered the chemical and pharmaceutical industry in India. He was aware that to sustain the industry and make it competitive in the world scene, it is necessary to reinvest a part of the profit for modernization and expansion. He wanted to develop the cotton industry for the benefit of the rural producers as well as the small investors. He himself appealed to the people to invest in indigenous industries and, when their investment was threatened, took upon himself the responsibility to safeguard it.

\section{BiBLIOGRAPHY}

Chakrabarti, Syamal. Oitihya Uttaradhikar O Bijnani Prafulla Chandra, Sahitya Samsad, Kolkata, 2011, p. 172.

Marx, Karl. The East India Company-Its History and Results, New-York Herald Tribune, London, Friday, June 24, 1853.

Mukherjee, D. edited, One Hundred Years of Triumps and Travails, A Biography of Bengal Chemical, Bengal Chemical and Pharmaceutical Ltd., Kolkata, 2004.

Rangarao, B V. Indian Drug Industry, Mainstream, 1 March 1975.

Ray, Prafulla Chandra. Bastroshilpe Bangali-Ashar Pathe (Bengali article), Basumati, Magh, 1344.

Ray, P C. Life and Experience of a Bengali Chemist, The Asiatic Society, Kolkata, 1996, Vol. I.

Sen G and Bose K C. Rauvolfia serpentina: a new Indian drug for insanity and high blood pressure, Indian Medical World, 11 (1931):194-201. 